\title{
ORIGINAL （2）
}

\section{超 高 解 像度 レプリカ}

\author{
安 達公 一*, 加藤勝**, 馬場 則 男*** \\ 篠 政 行***, 安 達 充 宏*, 金 谷 光 一*** \\ *東京大学工学部総合試験所 $\mathbf{T} 113$ 東京都文都区弥生 2-11-16 \\ **日製産業株式会社 S I センター \\ ***工学院大学電気工学科 $\mathbf{T} 160$ 東京都新宿区西新宿 1-24-2 \\ （1980年10月 8 日 受理）
}

\section{Ultra High Resolution Replica}

\section{Koichi Adachi*, Masaru Katoh**, Norio Baba***, Masayuki Shino***,} Mitsuhiro Adachi* and Koichi Kanaya***

\footnotetext{
*Engineering Research Institute, University of Tokyo, Yayoi-cho, Bunkyo-ku, Tokyo, Japan.

**Nissei Sangyo Co. Ltd., S. I. Center, 2 Nishi-shinbashi, Minato-ku, Tokyo, Japan.

***Department of Electrical Engineering, Kogakuin University, 1-24-2 Nishi-shinjuku, Shinjuku-ku,

Tokyo, Japan.
}

(Received October 8, 1980)

In high resolution observation of ultra-fine uneven surfaces of specimens, the image of replica films obtained by the normal single-stage replica method on specimen surfaces with uneven structure, less than $10 \mathrm{~nm}$ in size, is deformed by the evaporated materials, even though the thickness of the evaporated film is only a few $\mathrm{nm}$. Therefore, the smallest size of a replicated square-shaped object, that can be recognized as square shaped one, is about $5 \times 5 \mathrm{~nm}^{2}$.

In the new method, the unevenness of specimen surfaces is covered with evaporated film by conventional vacuum evaporation. As a result, fine details of surface structures are correctly removed with little deformation and are clearly observed in the replica image.

The smallest square shaped object, of $1.12 \times 1.12 \mathrm{~nm}^{2}$ size, that appeared in the replica image, is twice as large as the unit cell of $\mathrm{NaCl}$ crystal.

\section{1. はじめに}

ごく微細な表面の形態を透過電子顕微鏡で観察 するには，用いるレプリカの解像度を知る必要が ある。それには，レプリカ像で識別できる最小の 二線間を測定するより，試料面の四角い凸部が四 角い凸部のレプリカ像として，識別できる最小の

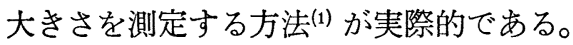

高解像度レプリカの蒸着一段法で識別できる最
小形態の限界は，これまで測定に適した試料面が 得られなかったことから， $\mathrm{MgO}$ 微結晶（立方体） のシャドウイング膜（金属の斜め蒸着）によるレ プリカ像の角の鈍化量を測定して，その結果から 識別できる最小の四角い凸部が求められている(2)。 それによると $\mathrm{Pt} / \mathrm{Pd}(8: 2)$ 合金のシャドウイン グでは， $5 \times 5 \mathrm{~nm}^{2}$ の四角い凸部が限界で，W/Ta (6:4) 合金のイオンビームスパッタリング・シ 
ヤドウイング(3) では, $1.3 \times 1.3 \mathrm{~nm}^{2}$ の四角い凸部 まで識別が可能としている。

しかし，それら試料面にある四角い凸部がレプ リカ像で観察される大ささは，レプリカ像が厚さ 2〜3nm のシャドウイング膜の観察像であるため, 試料面凸部よりかなり大さいことになる。それは， 試料面にある凹凸が大きさ $5 \mathrm{~nm}$ 以下になると， 凹凸の形態と大きさを正確に知ることができない し，よくてもその存在を知るに過ないことを意味 している。

以上に述べたレプリカの限界を解決するために は, $5 \times 5 \mathrm{~nm}^{2}$ 以下の四角い凸部が対象となるの で, これまでの原理と異なるレプリカ法が必要で ある。そのための超高解像度レプリカを目的とす る，新しいレプリカの原理㘧よび実験と考察を以 下に述べる。

\section{2. 原 理}

これまでのレプルカ像は, Fig 1. A に示すよう に，試料面の凹凸を被覆したシャドウイング金属 蒸着膜の透過像なので, その像コントラストに必 要な蒸着膜厚 $2 \sim 3 \mathrm{~nm}$ に対して, 観察対象となる
試料面の凹凸がごく微細になってくるほど, 蒸着 膜の厚みと角の鈍化 r (Fig. 1A) に影響され，試 料面の形態と大きさを正確に示さなくなる(4)。

新しいレプリカの像コントラストが得られる原 理は，Fig. 1B に示すように試料面の凹凸を真空 蒸着で埋立てたレプリカ膜の凹凸による膜厚差か ら，試料面の凹凸に対応する像コントラストが得 られる。従って, 新しい原理によるレプリカ像は, 被覆蒸着膜型のレプリカ像にあらわれる角の鈍化 が無く，乙かも凹凸像が示す横の寸法は試料面凹 凸の寸法と全く同じである。なお，レプリカした 凹凸の膜厚差から像コントラストを得る方法は, 古くプラスチックの一段レプリカ(5) があるが，解 像度の低いことから今は使用されていない。

3. 実 験

\section{3-1 レプリカの試料}

新しいレプリカの試料面に必要な条件は，すで に明らかな角をもつ形態を示し，その大きさが 1 〜 $5 \mathrm{~nm}$ の範囲にあり, しかも試料面に污れが全 く無いことを必要とする。それらにレプリカ作製 の容易さを考慮し，最適試料の作製を試みた結果,
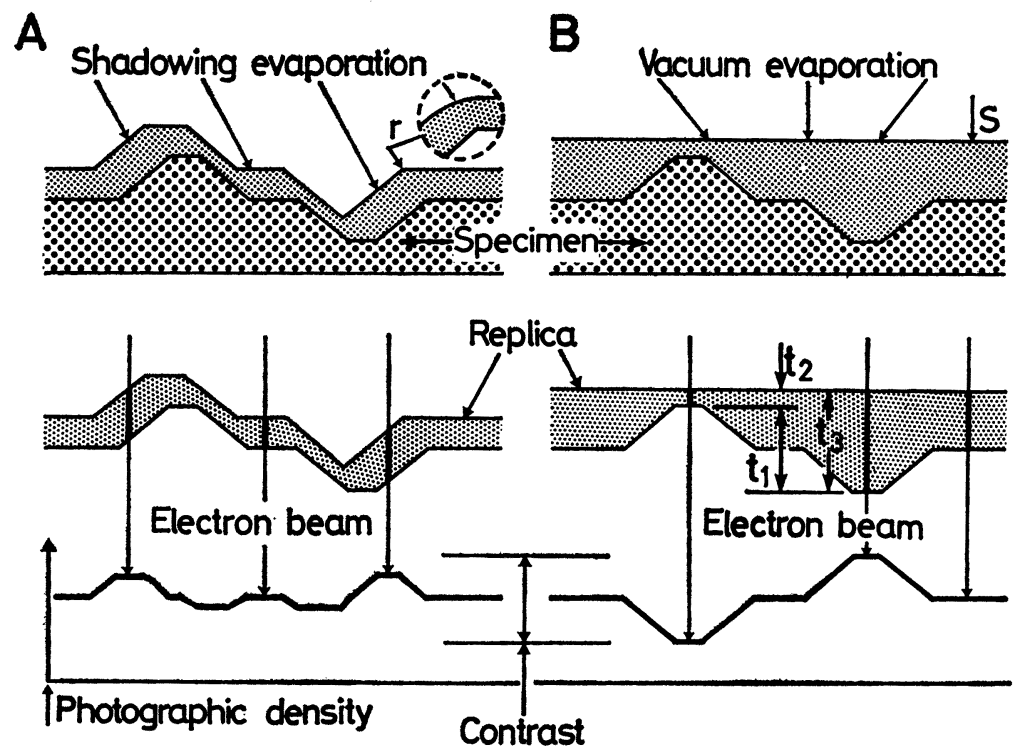

Fig. 1. Image formation of normal single stage replica and new one covering the unevenness of specimen surfaces with evaporated film by conventional vacuum evaporation. 
次に述べる $\mathrm{NaCl}$ を真空蒸着して作製した微結晶 面を用いた。

$\mathrm{NaCl}$ 微結晶の作製は, 真空度 $5 \times 10^{-7}$ Torr の 中で, $280^{\circ} \mathrm{C}$ に加熱したマイカの擘開面基板に,

$\mathrm{NaCl}$ を 5 10nm/ Sec の蒸着速度で, 膜厚約 350 $\mathrm{nm}$ に蒸着した。この $\mathrm{NaCl}$ 蒸着膜 ${ }^{(6)}$ は, (111) を主に（110）と（100）の方位に成長した微結晶 よりなることが解っている(7)。なお蒸着後の基板 温度は, $280^{\circ} \mathrm{C}$ から $230^{\circ} \mathrm{C}$ に低下させるのに約 15 分ほど必要とするため, 基板上の $\mathrm{NaCl}$ 微結晶面 に熱によるェッチングが加えられていると思われ る。

\section{3-2 レプリカの作製}

レプリカの蒸着材料は, 試料面の山凸を埋立て ることと撮影倍率を考虑して, 蒸着膜厚 $10 \mathrm{~nm}$ 以 下で特異構造が比較的見られない非晶質な Ge を 用いた。

レプリカの $\mathrm{Ge}$ 蒸着法は, 蒸発源にタングステ ン線のバスケットコイルを用い, 蒸着中の真空度 $5 \times 10^{-7}$ Torr とした。蒸着は, 試料面の凹凸を 埋立てたレプリカの膜が得られ，そのレプリカ面 の背面は平らに蒸着されることが望ましいので,

$\mathrm{NaCl}$ 試料を回転させながら行なった。試料の回

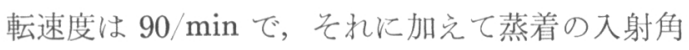
を45９0度の間で連続して変化させ，蒸着埋立て の効果を高めた。

レプリカの $\mathrm{Ge}$ 蒸着膜厚は, 試料面凹凸の大さ さと加速電圧 $100 \mathrm{KV}$ 電子線の透過能を考慮する と2 4nm で，実験では $3 \mathrm{~nm}$ を用いた。との測 定には水晶式膜厚計を用いた。

レプリカ膜を観察できる状態にするため, Ge 蒸着膜に垂直上から厚さ約 $8 \mathrm{~nm}$ のカーボン蒸着 して補強し, $\mathrm{NaCl}$ 面から水面剝難して, マイク ログリッドに支持した。

レプリカ試料の $\mathrm{NaCl}$ 微結晶面に注意したこと は, 真空排気系からの污れの堆積を防ぐため, そ の周囲をー $130^{\circ} \mathrm{C}$ に冷却した金属板で覆った。ま た微結晶面に及ぶ蒸発源の輻射熱を軽隇するため, 蒸発源も径 $5 \mathrm{~mm}$ の蒸発孔を持つ金属板で熱遮敞 した。

\section{3-3 レプリカ像の観察}

$\mathrm{NaCl}$ 蒸着面にめる微結晶の凹凸を蒸着の $\mathrm{Ge}$

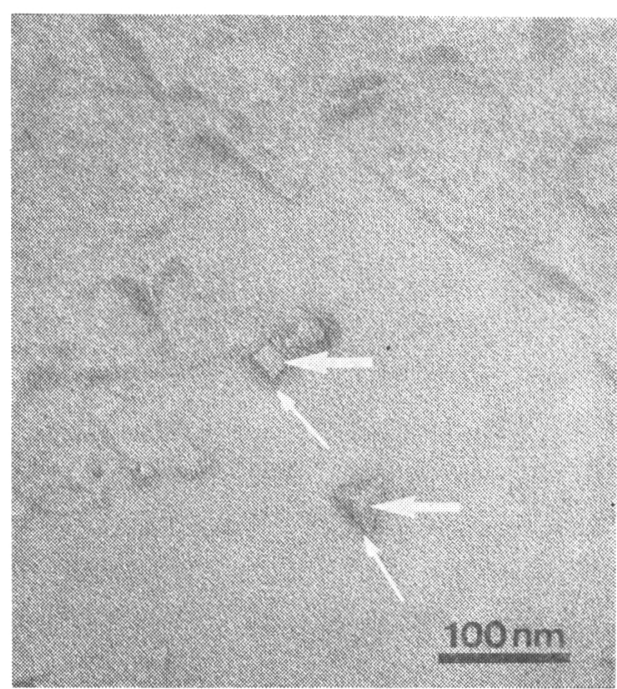

Fig. 2. Replida image obtained by new replica method covering the surface of evaporated $\mathrm{NaCl}$ with evaporated film.

原子が埋立てているかは，Fig. 2.の太い矢印で 指す部分像から確められる。太い矢印の部分は試 料面の大きな凸部なので, $\mathrm{Ge}$ 蒸着膜の厚さ $3 \mathrm{~nm}$ では被覆蒸着型のレプリカ像に近いが，その大き な凸部の周辺に写真黒化濃度が高いことは，凸部 の隅に $\mathrm{Ge}$ 原子が吹き溜まるように蒸着されたた めである。そのことはごく微細な凹凸面ならば, $\mathrm{Ge}$ 蒸着により埋立てたレプリカ膜が得られるこ とを示している。

Fig. 2 のレプリカ像に示す平坦な領域には, ご く微細な山凸らしきところは認められないが，と の領域を引伸し拡大した Fig. 3 には, $\mathrm{NaCl}$ 蒸 着面に各方位成長した微結晶の凹凸を見い出すこ とができる。それらの形態を示すレプリカ像の角 の鈍化はきわめて少ないので，形態を明確に識別 できる。

Fig. 3 の凹凸像は, 比較的よく形態を示す順に 矢印の大小順で示される。それらのうち最も小さ い凸部は矢印 $\mathrm{a}$ と $\mathrm{b}$ に示され，その四角い凸部は （100）の方位に成長した微結晶で, 四角の一辺の 長さが $1.12 \mathrm{~nm}$ であり, $\mathrm{NaCl}$ ユニットセル（0. $56 \mathrm{~nm}$ ) の二倍に一致する。

\section{4. 考 察}

4-1 レプリカ蒸着膜 
$\mathrm{Ge}$ 蒸着膜によるレプリカ像の欠点としてあら われる問題点は，レプリカの背面となる蒸着膜面 S (Fig. 1B) が， Ge 蒸着の性質による微細な敕 状構造を示すことである。これは観察対象となる 数 $\mathrm{nm}$ 大凹凸のレプリカ像に重なり，その形態の 識別を著しく阻害する。

レプリカと像コントラストに重要な蒸着膜厚は, 試料面にある凹凸の大きさと蒸着物質の密度で異 なるが, Fig. 1B に示すレプリカの $\mathrm{t}_{1}, \mathrm{t}_{2}, \mathrm{t}_{3}$ の各 膜厚について，加速電圧 $100 \mathrm{KV}$ 電子線の物質 透過能を考慮して検討してみた。それは， Ge 蒸 着膜厚の異なる、レプリカ膜と孔のある膜を重ね 合せ, そのレプリカの像コントラストと解像度か ら比較検討してみると， $\mathrm{t}_{1}$ 膜厚は像コントラスト の低下ょり $\mathrm{Ge}$ 蒸着膜面の礫状構造から $5 \mathrm{~nm}$ が 限界で，それに重なる $\mathrm{t}_{2}$ 膜厚の限度は $\mathrm{t}_{1}$ 膜厚の 40\%以内であった。

レプリカの蒸着面 S (Fig. 1B) は平面が望ま しいが，試料面凹凸の高低差が大きくなつてくる と，蒸着面も凹凸に沿ってなだらかな凹凸面にな る。その場合に試料面凹凸の大きさが $5 \mathrm{~nm}$ 以下 では, レプリカ像を余り阻害することがなかった。 しかし, 蒸着膜面 S の平面化は試料面凹凸の高低 差が大きいほど, 蒸着埋立ての必要から $t_{2}$ 膜が 厚くなり易い。そのようなレプリカ膜では像コン トラストが悪いので埋立て効果のよい蒸着法が必 要であり, 膜厚 $\mathrm{t}_{3}$ も $7 \mathrm{~nm}$ が限度である。

\section{4-2 レプリカの試料と形態識別能}

$\mathrm{NaCl}$ 蒸着面に $1 \mathrm{~nm}$ 大の微結晶が凹凸として 存在するかは推測できてもこれまでに確認されて おらず，確めるにもこのレプリカしか無い現状で ある。そこで Fig. 3 に示す凹凸像が， Ge 蒸着 膜からあらわれる疑似的な像かを確めるため, $\mathrm{NaCl}$ 単結晶およびマイカの䢃開面とガラス基板 面に, レプリカと同一条件で $\mathrm{Ge}$ 蒸着した膜を観 察した結果，それには凹凸らしき像も認められな かった。

透過電子顕微鏡（T EM）の形態識別の分解能 は，1nm 大の四角い適切な試料が得られないま まこれまでも確められていないので，Fig. 3 にあ る最小の四角い凹凸像が，TEMの分解能で撮影 可能かを検討する必要がある。
使用した TEM ( $\mathrm{H}-500 \mathrm{H})$ の点間隔分解能 は $0,2 \mathrm{~nm}$ で，これから識別できる最小の正四角 形の大きさを理論式(8) から求めてみると，それは 一辺の長さ $0.77 \mathrm{~nm}$ の正四角形である。従って, Fig. 3 の $\mathrm{NaCl}$ ユニットセル二倍の一辺の長さ を持つ四角い凸部は，充分に撮影可能である。な お, 用いた TEM の点間隔分解能 $0.2 \mathrm{~nm}$ は,

Fig. 3 においても矢印 cで示されている。

\section{4-3 レプリカの像コントラスト}

観察対象となる試料面凹凸の大きさが $5 \mathrm{~nm}$ 以 下になると，レプリカの膜厚差による散乱コント ラストのみで像解釈はできない。

Fig. 3 の矢印 d や細い線で直角に囲む凹凸で は, レプリカの膜厚差から得られている像コント ラストよりも，その凹凸の輪郭を示すコントラス トが形態を明確に示す要素となっている。この輪 郭もしくは外形を示す像コントラストは, 試料面 形態の弾性散乱波（外形回折波）の干渉によるコ ントラスト (9) と思われ，大きさ $20 \mathrm{~nm}$ 以下の形態 を示すレプリカ像のコントラストに寄与している。 この外形をよく示す像コントラストは, 蒸着埋立 型一段レプリカに重要である。

次に，試料面凹凸の大ささが $2 \mathrm{~nm}$ 程度以下に なってくると，位相コントラスト(10)による像の領 域になるため, 形態を示す像はディフォーカス量 で大きさと像コントラストが変化する。その例を 示す Fig. 4 は, $\mathrm{NaCl}$ 蒸着面のレプリカをスル ーフォーカスの撮影例で, アンダーフォカス A らDにジャストホーカスへ近ずくほど形態を示す 像は変化している。その中の矢印 $\mathbf{a}$ で示す一辺の 長さが $1.68 \mathrm{~nm}$ の四角い凸部は，形態と大きさを 著しく変えており, 同様に蒸着膜による粒状のノ イズも変化している。

以上のレプリカによる形態像が，位相コントラ ストで正しく示されるディフォーカス量 $(\Delta \mathrm{f})$ は, 形態の大きさで異なる。Fig. 4 の矢印aに示す 大きさの場合では, そのスルーフォーカス撮影の 結果から求めると $\Delta \mathrm{f}=240 \mathrm{~nm}$ 前後であり, 理論 式(10) から求めてみると $\Delta \mathrm{f}=310 \mathrm{~nm}$ が得られ， $\Delta \mathrm{f}$ 量に許容幅を考慮すると両者はかなりよく合う。

しかし，レプリカ蒸着膜自体の特異構造や粒状 のノイズ像に，レプリカの形態像が阻害されるこ 


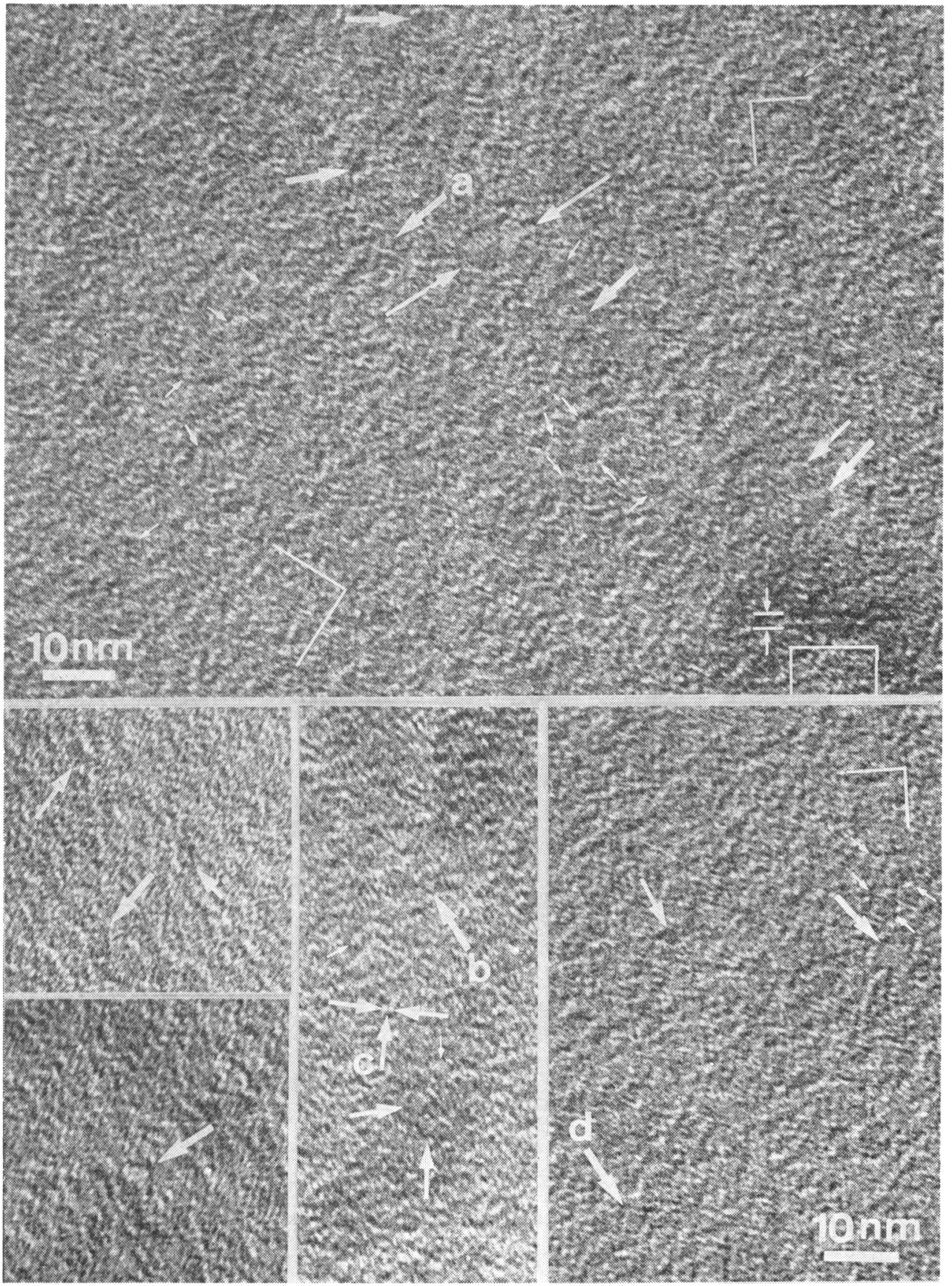

Fig. 3. Replica image appearing very fine uneven surface of evaporated $\mathrm{NaCl}$ by new replica method. 

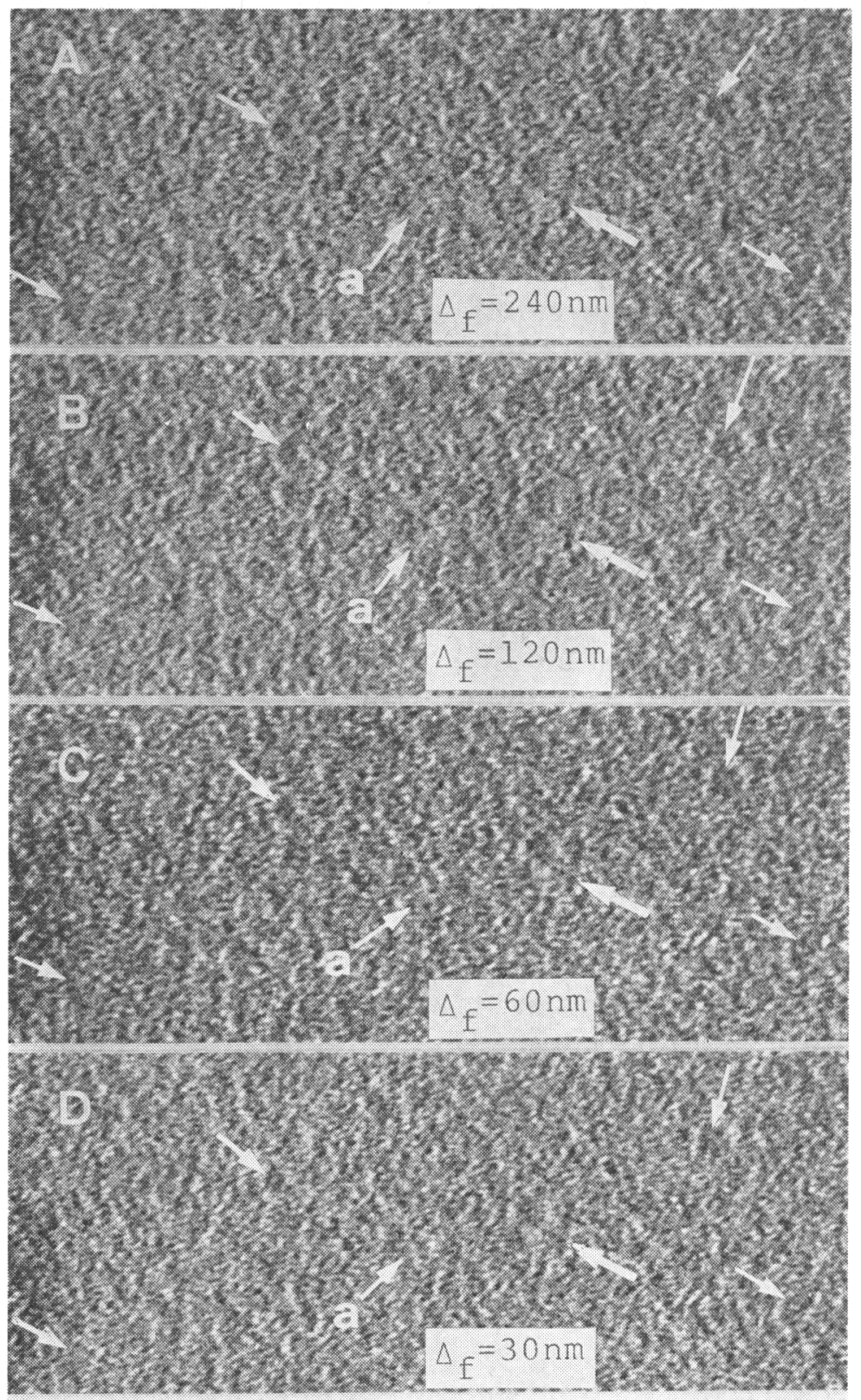

$10 \mathrm{~nm}$

Fig. 4. Through focus replica images of micro-crystals on the evaporated $\mathrm{NaCl}$ surface.

とは，或る程度の改善が可能としても，蒸着によ るレプリカ膜を用いる限りノイズを無くすことが できない。その解決には, 画像処理法の導入が必 要である。

\section{5. 結 論}

新しいレプリカ法の原理は, 試料面の凹凸を $\mathrm{Ge}$ 蒸着で埋立てたレプリカにより, 試料面の凹 凸と対応したレプリカ膜凹凸の形態と厚み差から 
像コントラストが得られた。それによって，これ までの被覆蒸着型のレプリカ膜の厚みと角の鈍化 による，試料面形態がレプリカ像で変形する因子 を除くことができた。従って，新しいレプリカの 試料像が示す横の長さは, 試料面の形態そのもの の長さで, 凹凸像の関係も像コントラストの差か ら識別が容易となった。

以上によって, 蒸着埋立型一段レプリカの解像 度としては， $1.12 \times 1.12 \mathrm{~nm}$ の四角い凸部まで識 別できた。これはレプリカによる表面形態の定量 的観察が, 高分解能 T EMの形態識別の分解能ま でほぼ可能になったことを示し，超高解像度レプ リカに到達した。

今後における課題は, 新しいレプリカの像コン トラストを明らかにして，残された問題点である レプリカ蒸着膜のノイズを改善することである。 特に後者は蒸着に関する改善の外に，画像処理を 利用する必要がある。
文

\section{献}

(1) R. D. Heidenreich: J. Appl. Phys. 14 (1943) 312

(2) K. Adachi, K. Hojou, M. Katoh, and K. Kanaya: Ultramicroscopy 2 (1976) 17

(3) K. Kanaya, K. Hojou, K. Adachi, and K. Toki : Micron 5 (1974) 89

（4）安達公一：電子顕微鏡 13 (1978） 48

(5) H. Mahl : Z. Tech. Phys. 22 (1941) 23

(6) G. A. Bassett and D. W. Pashley: J. Inst. Metals, 87 (1958) 449

(7) I. Ogura, S. Hayashi and T. Hirokawa: J. Electron Microscopy 13 (1964) 173

(8) B. von Barries and G. A. Kausche: Kolloid-Z. 9 (1940) 123

(9) K. Kanaya, Y. Inoue and A. Ishikawa: J. Electron Microscopy 2 (1954) 1

(10) F. Thon: Z. für Naturforschg. 21a (1966) 476 